Contents of Nos 1-12

III-XIV

\section{Original Communications}

Identification of Betulin in Archaeological Tar (In German)

F. Sauter, E. W. H. Hayek, W. Moche, and

U. JORDIS

1151

Chemical Composition and Morphology of Epicuticular Waxes from Leaves of Solanum tuberosum

A. SEN

1153

Asymmetric Reduction of 4(5)-Oxocarboxylic Acids by Baker's Yeast (In German)

M. Gessner, C. Günther, and A. Mosandl 1159

Partial Lack of N-Acetyl Substitution of Glucosamine in the Peptidoglycan of the Budding Phototrophic Rhodomicrobium vannielii

U. J. Jürgens, B. Rieth, J. Weckesser, C. S. Dow, and W. A. KöNIG

1165

Accumulation of Phenolic Compounds and Phytoalexins in Sliced and Elicitor-Treated Cotyledons of Cicer arietinum $\mathrm{L}$.

U. Jaques, H. Kessmann, and W. Barz

Natural Inhibitors of Germination and Growth IV Compounds from Fruit and Seeds of Mountain Ash (Sorbus aucuparia)

U. OSTER, I. Blos, and W. Rüdiger

The $v$ versus $v[I]$ Plot

A. C. Borstlap

Development of New Plate Tests for the Detection of Microbial Hydrolysis of Esters and Oxidations of 2-Hydroxycarboxylic Acids (In German)

Y. Yamazaki and M.-R. Kula 1187

Enzymatic Synthesis of $4^{\prime}$ - and $3^{\prime}, 4^{\prime}$-Hydroxylated Flavanones and Flavones with Flower Extracts of Sinningia cardinalis

K. STICH and G. ForkMANN

1193

Purification and Properties of Chalcone Synthase from Cell Suspension Cultures of Soybean

R. Welle and H. Grisebach

1200
4-(2'-Carboxyphenyl)-4-oxobutyryl Coenzyme A Ester, an Intermediate in Vitamin $\mathrm{K}_{2}$ (Menaquinone) Biosynthesis

R. Kolkmann and E. Leistner

1207

Role of Pyrophosphate: Fructose-6-phosphate 1-Phosphotransferase in Glycolysis in Cultured Catharanthus roseus Cells

H. Ashihara and T. Horikosi

1215

The Separation of Two Different Enzymes Catalyzing the Formation of Hydroxycinnamic Acid Glucosides and Esters

P. A. BäUmKer, M. JütTE, and R. Wiermann 1223

Protein Sequence and Structure of N-terminal Amino Acids of Subunit Delta of Spinach Photosynthetic ATP-Synthase $\mathrm{CF}_{1}$

R. J. Berzborn, W. Finke, J. Otto, and H. E. MEYER

1231

Isolation and Characterization of a Supramolecular Complex of Subunit III of the ATP-Synthase from Chloroplasts

P. Fromme, E. J. Boekema, and P. Gräber 1239

The Polyphasic Rise of Chlorophyll Fluorescence upon Onset of Strong Continuous Illumination: I. Saturation Characteristics and Partial Control by the Photosystem II Acceptor Side

$\mathrm{Ch}$. Neubauer and U. Schreiber

1246

The Polyphasic Rise of Chlorophyll Fluorescence upon Onset of Strong Continuous Illumination: II. Partial Control by the Photosystem II Donor Side and Possible Ways of Interpretation U. Schreiber and Ch. Neubauer

1255

Benzofuroxan as Electron Acceptor at Photosystem I B. Lotina-Hennsen, A. Garcia, M. Aguilar, and M. Albores 1265

CARS Investigation of Changes in Chromophore Geometry of C-Phycocyanin from Mastigocladus laminosus Induced by Titration with $p$-Chloromercuribenzenesulfonate

S. Schneider, F. BaumanN, and U. KLÜTer 1269

Inhibition by Sethoxydim of Pigment Accumulation and Fatty Acid Biosynthesis in Chloroplasts of Avena Seedlings

H. K. Lichtenthaler, K. Kobek, and K. IshiI

1275

Continued overleaf 
Bioenergetics Studies of the Cyanobacterium Anabaena variabilis

S. Scherer, H. SADOWSKI, and P. Böger

1280

Radiochemical Methods for Studying Lipase-Catalyzed Interesterification of Lipids

R. SCHUCH and K. D. MuKhERJEe

1285

cAMP-Dependent Protein Kinase Activity in Yeast Mitochondria

G. MülLER and W. BANDLOW

1291

Twisted Fibrils are a Structural Principle in the Assembly of Interstitial Collagens, Chordae Tendineae Included

W. Folkhard, D. Christmann, W. Geercken, E. Knörzer, M. H. J. Кoch, E. Mosl.er, H. Nemetschek-Gansler, and T. Nemetschek 1303

Lysine Decarboxylase from Hafnia alvei: Purification, Molecular Data and Preparation of Polyclonal Antibodies

H. BeIER, L. F. Fecker, and J. Berlin

1307

Recognition of HLA Class II Molecules by Antipeptide Antibodies Elicited by Synthetic Peptides Selected from Regions of HLA-DP Antigens

A. Chersi, R. A. Houghten, M. C. Morganti, and E. Muratti

1313

Active Cyanogenesis - in Zygaenids and Other Lepidoptera

K. Witthohn and C. M. NaumanN

Efficacy of Sustained-Release Radioprotective Drugs in vivo

J. Shani, S. Benita, M. Abdulrazik, and A. Yerushalmi

1323

MHC-Antigens: Constituents of the Envelopes of Human and Simian Immunodeficiency Viruses

H. Gelderblom, H. Reupke, T. Winkel, R. Kunze, and G. PAULI 1328

Evidences for Circadian Rhythmicity in the per ${ }^{\circ}$ Mutant of Drosophila melanogaster

Ch. Helfrich and W. EngelmanN

1335

\section{Notes}

Conformational Changes in Proteins Induced by Low Temperatures: an Infrared Study

H. L. Casal, U. Köhler, H. H. Mantsch, F. M.

GoÑI, and J. L. R. ARrondo

1339
Thermal Lability of Membrane Proteins of Age Separated Erythrocytes as Studied by Electron Spin Resonance Spin Label Technique

G. Bartosz, G. Christ, H. Bosse, R. Stephan, and H. GäRTNER

1343

Lipids in the Gular Gland Secretion of the American Alligator (Alligator mississippiensis)

P. J. Weldon, A. Shafagati, and J. W. Wheeler

Identification of the Sex Pheromone of Eggplant Borer Leucinodes orbonalis Guenèe (Lepidoptera: Pyralidae)

Z. Pingchou, K. Fanlei, Y. Shengdi, Y. YongQIng, J. Shuping, H. XINhUa, and X. JianweI

1347

(Z)-5-Dodecen-1-ol, Another Inhibitor of Pheromonal Attraction in Coleophora laricella

E. Priesner

1349

(Z)-3-Tetradecenyl Acetate as a Sex-Attractant Component in Gelechiinae and Anomologinae (Lepidoptera: Gelechiidae)

E. PRIESNer

1352

Mammalian Pheromone Studies, VI. Compounds from the Preorbital Gland of the Blue Duiker, Cephalophus monticola

B. V. Burger and P. J. Pretorius

1355

Structural Features and Biological Functions in Blue Copper Proteins

Y. NISHIDA

1358

Inhibition of the Acetyl-CoA Carboxylase of Barley Chloroplasts by Cycloxydim and Sethoxydim

M. Focke and H. K. Lichtenthaler

1361

Formation of Large Thioredoxin $f$ Accompanies Chloroplast Development in Scenedesmus obliquus

P. LANGlotz and H. FollmanN 1364

Cellular Spin Resonance of Yeast in a Frequency Range up to $140 \mathrm{MHz}$

R. HöLZEL and I. LAMPRECHT

Melting Pressure, Volume and Stability of Blood at High Pressure (In German)

A. KLuge and H. Lentz

Subjekt Index

Authors Index

1403 


\title{
cAMP-Dependent Protein Kinase Activity in Yeast Mitochondria
}

\author{
Günter Müller* and Wolfhard Bandlow \\ Institut für Genetik und Mikrobiologie der Universität München. Maria-Ward-Straße 1 a. \\ D-8000 München 19. Bundesrepublik Deutschland
}

Z. Naturforsch. 42c, 1291-1302 (1987); received May 29/August 3, 1987

cAMP-Dependent Protein Kinase, Protein Phosphatase, Yeast. Mitochondria, Sub-Mitochondrial Location

Two different cAMP-binding proteins have been identified in yeast mitochondria by photoaffinity labelling and based on the occurrence of cAMP-binding activity in two different sub-mitochondrial fractions. One protein $\left(M_{\mathrm{r}} 45-46000\right)$ is tightly bound to the inner mitochondrial membrane whereas the other $\left(M_{\mathrm{r}} 42000\right)$ is found in the soluble intermembrane space. With endogenous substrate cAMP-dependent protein kinase activity could not be demonstrated with sufficient clarity. However, using acidic heterologous substrates, like casein and phosvitin, one cAMP-dependent protein kinase was identified in the intermembrane space. Only low phosphate incorporation was found using histone fractions as substrate. cAMP-dependent modification of proteins appears to be very shortlived in mitochondria. Its physiological significance remains unknown, since neither mitochondrial transcription, translation, respiration nor import of cytoplasmically synthesized precursors into mitochondria appear to be influenced by exogenous cAMP either in vivo or in vitro. It is shown that cAMP is not actively transported into the inner mitochondrial compartment but rather binds to a receptor(s) localized outside the permeability barrier provided by the inner membrane.

\section{Introduction}

Based on the existence of $\mathrm{Mg}^{2+}$-dependent. guanine nucleotide sensitive adenylate cyclase [1], phosphodiesterase [2], cAMP-binding protein [3-5] and cAMP-dependent protein kinase activity [6] in yeast, it has been postulated that in this ascomycete. like in mammalian tissues, cAMP exerts its physiological effects through the activation of a cAMP-dependent kinase. In turn, this enzyme controls the activity of several proteins by phosphorylation/dephosphorylation. Apart from the well documented involvement in the control of storage carbohydrate metabolism [7, 8] and of the cell division cycle [9-11], a possible role of cAMP was also discussed in relation to carbon catabolite repression [12-17]. Namely it was reported that cAMP, added to glucose-grown yeast cells, effects a partial release from carbon catabolite repression of several mitochondrial functions, e.g. of porphobilinogen synthetase activity [18], of the synthesis of mitochondrially encoded

\footnotetext{
* Present address: Institut für physiologische Chemie, physikalische Biochemie und Zellbiologie der Universität München. Goethestraße 33, D-8000 München 2.
}

Reprint requests to $\mathrm{Dr}$. Wolfhard Bandlow, Institut für Genetik und Mikrobiologie, Maria-Ward-Straße 1 a. D-8000 München 19.

Verlag der Zeitschrift für Naturforschung, D-7400 Tübingen $0341-0382 / 87 / 1100-1291 \$ 01.30 / 0$ subunits of cytochrome oxidase [19] and of mitochondrial respiration [20]. But the validity of this approach is uncertain, since it has been observed that catabolite repression in yeast is not associated with low levels of cAMP $[14,15,21]$. Consequently a role in the adaptation of mitochondrial function to the carbon source supply in the growth medium could not be assigned to CAMP. On the other hand, recent findings unequivocally prove that cAMP plays some part in the biogenesis and/or function of mitochondria. Ras proteins - the yeast analogs to the $\mathrm{p} 21$ products of mammalian ras protooncogene products [22] - were shown to control adenylate cyclase activity in yeast in vivo $[23,24]$ and after cloning in $E$. coli [25]. Destroying RAS2 gene function in yeast by disruption of the respective structural gene (one of the two RAS loci found in yeast), leads to an extremely low level of cAMP. Among other pleiotropic effects (concerning utilization of storage carbohydrates, mitosis and sporulation) these mutants exhibit a respiratory deficient phenotype $[23,26]$. In addition, it was found that yeast RAS $2^{\text {val } 19}$ mutants, altered at a position analogous to the transforming viral or cellular ras $^{\text {val12 }}$ oncogene product of mammalian cells, synthesize increased levels of cAMP and show exactly the opposite phenotype as ras 2 disruptions [24, 27]. These cells have giant mitochondria and exhibit enhanced mitochondrial respiration (J. Mattoon, unpublished results). These latter findings suggest that 
cAMP plays an important role in the biogenesis of mitochondria - although possibly not in the mediation of their response to glucose repression. But as yet it is completely unknown whether this control is exerted solely by the soluble cytoplasmic cAMPdependent protein kinase or if mitochondria themselves possess a certain autonomy in this respect. An indication of the latter possibility was recently provided by the documentation of a cAMP-binding protein inside yeast mitochondria $[28,29]$. Here we present some evidence that cAMP binds to two different mitochondrial cAMP-binding proteins. One $\left(M_{\mathrm{r}}\right.$ 45-46000) is tightly bound to the inner membrane and the other $\left(M_{\mathrm{r}} 42000\right)$ is a soluble protein of the intermembrane space. We report that both endogenous and exogenous (acidic) substrates are phosphorylated in a cAMP-dependent manner, indicating that at least one cAMP-dependent protein kinase resides in the soluble intermembrane space as well. A physiological role could not yet be assigned to this kinase activity as mitochondrial respiration, transcription, translation or import into mitochondria of precursors for mitochondrial proteins synthesized on cytoplasmic ribosomes are not significantly influenced by cAMP either in vivo or in isolated mitochondria.

\section{Materials and Methods}

Growth of strains and preparation of mitochondria and mitochondrial subfractions

Cells of strains D273-10B (ATCC 25657) or DH 1 $\mathrm{op}_{1}$ were grown on lactate $(2 \%)$, glycerol $(2 \%)$, glucose $(6 \%)$ or galactose $(1.8 \%)$ as indicated, harvested and converted to spheroplasts using Zymolyase 100000 (Miles, Frankfurt) and lysed osmotically [30]. Alternatively, cells were broken by careful shaking with glass beads by hand [31]. Mitochondria, isolated by differential centrifugation $(3000 \times \mathrm{g}$, $10 \mathrm{~min}$, to $9750 \times \mathrm{g}, 15 \mathrm{~min}$ ), were further purified by centrifugation on isokinetic Urographin gradients (Schering AG, Berlin) prepared by two rounds of freezing and thawing of $40 \%$ Urographin in $20 \mathrm{~mm}$ $\mathrm{NaP}_{i}, 0.5 \mathrm{~mm}$ EDTA, $0.5 \mathrm{~mm}$ dithiothreitol, $0.5 \mathrm{~mm}$ phenylmethylsulfonyl fluoride, $\mathrm{pH}$ 7.0. The fraction containing intact mitochondria (banding at $42 \%$ Urographin) was sedimented after twofold dilution $(25000 \times g, 20 \mathrm{~min})$. Subfractionation into intermembrane space, matrix and inner and outer mem- branes was achieved in the same way as described [28].

Enzyme assays, photoaffinity labelling and protein determination

The assays of specific subcellular and submitochondrial markers followed published procedures [28]. cAMP-binding was alternatively measured by a filter binding assay [32] or by equilibrium dialysis [28].

Protein kinase activity was measured as follows: $100 \mu \mathrm{g}$ of dialyzed protein of each fraction was incubated in $100 \mu \mathrm{l}$ (final volume) of buffer (20 mM Tris. $5 \mathrm{~mm} \mathrm{MgCl}, 10 \mathrm{~mm}$ dithiothreitol, $50 \mu \mathrm{M}$ EDTA, $50 \mu \mathrm{M}$ phenylmethylsulfonyl fluoride, $\mathrm{pH}$ 6.8) at $30{ }^{\circ} \mathrm{C}$ either in the presence or absence of $2 \mu \mathrm{M}$ cAMP. Protein kinase activity with exogenous substrates was assayed with $50 \mu \mathrm{g}$ mitochondrial protein plus $50 \mu \mathrm{g}$ of partly dephosphorylated casein, phosvitin, or of bovine serum albumin or histone (Type $V$ and Type VIII, Sigma). In partial reconstitution experiments the incubation mixture contained $50 \mu \mathrm{g}$ protein, each of the intermembrane space and of inner membranes. The phosphorylation reaction was started by the addition of $5 \mu \mathrm{Ci} \gamma-\left[{ }^{32} \mathrm{P}\right] \mathrm{ATP}$ in a volume of $5 \mu \mathrm{l}(3.35 \mathrm{Ci} / \mathrm{mmol}$, final concentration $15.2 \mu \mathrm{M})$ and terminated after $30 \mathrm{~min}$ or at times indicated by the addition of $10 \mu \mathrm{l}$ of $50 \%$ trichloroacetic acid, $5 \%$ sodium dodecylsulfate. $100 \mathrm{~mm}$ ATP.

$10 \mu \mathrm{l}$ of each assay were spotted on filters in triplicate, washed for $16 \mathrm{~h}$ with several changes of $5 \%$ trichloroacetic acid (containing, in addition, $2 \mathrm{~mm}$ sodium pyrophosphate, $2 \mathrm{~mm}$ adenine sulfate), which removed acid-labile phosphate adducts, and two times with ethanol. Dry filters were counted in $2 \mathrm{ml}$ toluene-based scintillation cocktail.

Cellular respiration was measured [33] in a gastight thermostated vessel $(2.5 \mathrm{ml})$ equipped with a Clarke-type polarographic electrode at $25^{\circ} \mathrm{C}, \mathrm{O}_{2}$ saturation $0.253 \mu \mathrm{mol} / \mathrm{ml}$.

Photoaffinity labelling experiments were performed essentially as described [34]. $100 \mu \mathrm{g}$ of mitochondrial protein were incubated in a final volume of $100 \mu$ lof a buffer containing $50 \mathrm{~mm}$ MOPS, $50 \mathrm{~mm} \mathrm{NaCl}, 10 \mathrm{~mm} \mathrm{MgCl}_{2}, 0.1 \mathrm{~mm}$ 5'-AMP, $50 \mu \mathrm{m}$ EDTA, $1 \mathrm{~mm}$ isobutylmethyl xanthin, $0.5 \mathrm{~mm}$ dithiothreitol, $0.5 \mathrm{~mm}$ phenylmethylsulfonyl fluoride, $\mathrm{pH} 7.2$, and $0.5 \mu \mathrm{Ci} 8-\mathrm{N}_{3}\left[{ }^{32} \mathrm{P}\right] \mathrm{CAMP}(50 \mathrm{Ci} /$ 
mmol) in the absence or presence of $100 \mu \mathrm{m}$ unlabeled cAMP as a competitor (for demonstration of specificity of the binding) in the dark for $15 \mathrm{~min}$ at $\left({ }^{\circ} \mathrm{C}\right.$. Then the sample was exposed to UV light illumination (Hanau NN 15/44 V) at a distance of approximately $5 \mathrm{~cm}$ for $4 \mathrm{~min}$ at $0^{\circ} \mathrm{C}$. The reaction was terminated by adding $50 \mu \mathrm{l} 3 \times$ SDS sample buffer, followed by heating to $95^{\circ} \mathrm{C}$ for $2 \mathrm{~min}$, before samples were subjected to SDS polyacrylamide gel electrophoresis.

Protein was determined both by the methods of Bradford [35] and Heil and Zillig [36].

\section{In vivo mitochondrial transcription and translation}

For measuring mitochondrial macromolecular syntheses in vivo, cells were grown over night in synthetic medium in the presence of $0.1 \mu \mathrm{Ci} / \mathrm{ml}$ of either $\left[{ }^{14} \mathrm{C}\right]$ isoleucine or $\left[{ }^{1+} \mathrm{C}\right]$ adenine as a prelabel. After the application of a chase each culture (titer $2-4 \times 10^{7}$ cells $/ \mathrm{ml}$ ) was divided into two portions for pulse labelling. One of these received $2 \mathrm{~mm} \mathrm{~N} \mathrm{~N}^{6}$ monobutyryl cAMP. A single-labeled sample was kept for the determination of the spill-over. $4 \mathrm{ml}$ aliquots were pulsed for $15 \mathrm{~min}$ after $1 \mathrm{~h}$ of incubation with the cAMP derivative.

For labelling mitochondrially made proteins the cells received $100 \mu \mathrm{g} / \mathrm{ml}$ cycloheximide and. $90 \mathrm{sec}$ later, $50 \mu \mathrm{Ci}\left[{ }^{3} \mathrm{H}\right]$ leucine. To compensate for possible cAMP-induced changes in the size of the cellular leucine pool, the label was diluted to a specific radioactivity of $80 \mathrm{mCi} / \mathrm{mmol}(160 \mu \mathrm{m}$, which was determined to correspond to about $90 \%$ pool saturation for leucine in yeast (W. Bandlow, unpublished data). The incorporation was terminated after $15 \mathrm{~min}$ by a $10 \mathrm{~min}$ chase. Labeled cells were broken by vortexing with glass beads in an Eppendorf cup. debris were removed by low speed centrifugation and mitochondria sedimented and purified by centrifugation through a $0.4 \mathrm{ml}$ cushion of $40 \%$ Urographin for $20 \mathrm{~min}$ in an Eppendorf centrifuge. The supernatant was removed by suction, the pellet dissolved in buffer containing $2 \%$ sodium dodecylsulfate and the suspension spotted on glass fiber filters. previously soaked with $5 \%$ trichloroacetic acid, $5 \mathrm{~mm}$ in each, leucine and isoleucine. The filters were washed three times with the same solution. once with ethanol and once with ethanol/ether (1:1). Dry filters were counted as above. ${ }^{3} \mathrm{H}$-counts incorporated during the pulse were normalized to 1000 ${ }^{1+} \mathrm{C}$-counts of the prelabel.
For measuring mitochondrial transcription $4 \mathrm{ml}$ of a similar cell culture, pre-labeled with $\left[{ }^{14} \mathrm{C}\right]$ adenine, received $50 \mu \mathrm{Ci}\left[{ }^{3} \mathrm{H}\right]$ uracil, diluted to a specific radioactivity of $140 \mathrm{mCi} / \mathrm{mmol}(90 \mu \mathrm{M})$, for the same reasons mentioned before for leucine (W. Bandlow, unpublished results). The incorporation was chased, cells broken and mitochondria prepared as described above. The pellet containing purified mitochondria was resuspended in $0.15 \mathrm{ml} 10 \mathrm{~mm}$ Tris. $1 \mathrm{~mm}$ EDTA, pH 7.0, and lysed at $60^{\circ} \mathrm{C}$ by the addition of $0.2 \%$ sodiumdodecylsulfate (final concentration). An equal volume of phenol ( $\mathrm{pH} 7.0$ ) was immediately added for deproteination, followed by $0.15 \mathrm{ml}$ of chloroform. The extraction was repeated two times. Nucleic acids were then precipitated from the aqueous phase by $2.5 \mathrm{vol}$ ethanol and dissolved in $10 \mathrm{~mm}$ Tris, $1 \mathrm{~mm}$ EDTA, pH 7.0. Unlabelled mitochondrial DNA was prepared separately, purified by $\mathrm{NaJ}$ gradient centrifugation, denatured, and $\delta \mu \mathrm{g}$ of the DNA bound to nitrocellulose paper discs. After drying and baking at $80^{\circ} \mathrm{C}$ under reduced pressure for $2 \mathrm{~h}$ the discs were prehybridized in $0.1 \mathrm{ml}$ of $0.9 \mathrm{M}$ $\mathrm{NaCl}, 0.09 \mathrm{~m}$ sodium citrate $(6 \times \mathrm{SSC}), 1 \times$ Denhardt's solution, $0.1 \%$ sodium dodecylsulfate. $50 \%$ deionized formamide and $100 \mu \mathrm{g} / \mathrm{ml}$ of sonified, deproteinized and denatured herring sperm DNA at $35^{\circ} \mathrm{C}$ for $4-6 \mathrm{~h}$ and then hybridized with the labeled RNA over night under the same conditions. After washing (two times $2 \times \mathrm{SSC} .60^{\circ} \mathrm{C}$. vortexing for $1 \mathrm{~min}$, once in $0.1 \times \mathrm{SSC}$ at room temperature, once with ethanol) dry filters were counted and evaluated as described above. A blank filter was used for background determination.

\section{Transcription and translation in isolated mitochondria}

For measuring macromolecular syntheses in isolated mitochondria, spheroplasts were prepared as described above and granted a recovery phase of $60 \mathrm{~min}$ in complete medium stabilized with $1 \mathrm{~m}$ sorbitol [30]. Spheroplasts were lysed by osmotic shock and mitochondria purified by differential centrifugation.

Measurement of mitochondrial protein synthesis in organello employed an endogenous ATP-regenerating system, similar to the one described by Grivell [37], which additionally contained $150 \mu \mathrm{m}$ GTP. Labelling was performed with $50 \mu \mathrm{Ci}$ $\left[{ }^{3} \mathrm{H}\right]$ leucine in a final volume of $0.1 \mathrm{ml}$ with $160 \mu \mathrm{g}$ mitochondrial protein in the presence or absence of 
$25 \mu \mathrm{M}$ cAMP. It was terminated after $20 \mathrm{~min}$ by a chase of $10 \mathrm{~min}$. (The reaction is insensitive to cycloheximide, sensitive to uncoupler, oligomycin, and chloroamphenicol and is linear for at least $30 \mathrm{~min}$ [33].) Mitochondria were spotted on glass fiber filters, washed and counted.

The same mitochondria as above were used for measuring mitochondrial transcription. The incubation conditions described previously [29] were used and transcripts labeled by the addition of $1 \mu \mathrm{Ci}$ $\left[{ }^{3} \mathrm{H}\right] \mathrm{UTP}$ in the presence or absence of $25 \mu \mathrm{M}$ cAMP. Both, run-off transcription in intact mitochondria and poly $(\mathrm{dA} \cdot \mathrm{dT})$-directed RNA synthesis in mitochondrial lysates were assayed. In the first case the medium contained $0.6 \mathrm{~m}$ mannitol, in the latter $1 \%$ Nonidet $\mathrm{P} 40$ and $0.1 \mu \mathrm{g}$ poly $(\mathrm{dA} \cdot \mathrm{dT})$. The incorporation was terminated after $10 \mathrm{~min}$ (for which the reaction is linear with time) by the addition of a chase for $10 \mathrm{~min}$. Mitochondrial suspensions were spotted onto glass fiber filters, washed and counted as above, except that the $5 \%$ trichloroacetic acid contained $2 \mathrm{~mm}$ sodium pyrophosphate and $2 \mathrm{~mm}$ uridine. The reaction is insensitive to $100 \mu \mathrm{g} / \mathrm{ml}$ $\alpha$-amanitin, but completely inhibited by $25 \mu \mathrm{g} / \mathrm{ml}$ actinomycin D or $15 \mu \mathrm{g} / \mathrm{ml}$ acriflavin.

A crude preparation of mitochondrial RNA polymerase was obtained from mitochondria lysed in $1 \%$ Nonidet P40 after successive chromatography on Sephacryl S300 and heparin Sepharose as described $[29,38]$. Transcription was measured in the presence or absence of $25 \mu \mathrm{M}$ cAMP with $0.1 \mu \mathrm{g}$ of poly$(\mathrm{dA} \cdot \mathrm{dT})$ as a template as described above for mitochondrial lysates.

\section{Import of precursor protein into mitochondria in vivo and in vitro}

For measuring import of precursor protein into mitochondria in vivo and in vitro, cells were grown in either $12 \%$ glucose or $2 \%$ lactate as the carbon source. At a titer of $3 \times 10^{7}$ cells $/ \mathrm{ml}$ cells were converted to spheroplasts. After a recovery phase of $1 \mathrm{~h}$ in the same medium containing $1 \mathrm{~m}$ sorbitol [30]. spheroplasts were re-collected by centrifugation, washed and resuspended in synthetic medium containing $1 \mathrm{~m}$ sorbitol. Import was then impaired by destroying the membrane potential by $200 \mu \mathrm{M}$ carbamyl cyanide m-chlorophenyl hydrazone, thus allowing the accumulation of mitochondrial precursor proteins in the cytoplasm [39]. After a preincubation period of $10 \mathrm{~min}$ the total products of cytoplasmic protein synthesis were labeled after the addition of $2 \mu \mathrm{Ci}\left[{ }^{35} \mathrm{~S}\right]$ methionine. The labelling was terminated after $10 \mathrm{~min}$ by a chase together with the addition of $50 \mathrm{~mm} \beta$-mercaptoethanol to restore energy coupling and initiate import into mitochondria [40]. The culture was immediately divided into two portions, one of which received $5 \mathrm{~mm}$ cAMP. Spheroplasts were harvested after $30 \mathrm{~min}$, washed, broken by osmotic shock, mitochondria prepared and freed from labeled material adhering to the outer surface by incubation with $20 \mu \mathrm{g} / \mathrm{ml}$ trypsin at $0{ }^{\circ} \mathrm{C}$ [40]. This digestion was terminated after $15 \mathrm{~min}$ by the addition of $50 \mu \mathrm{g} /$ $\mathrm{ml}$ of soybean trypsin inhibitor and $2 \mathrm{~mm}$ tosyl lysyl chloromethyl ketone. $100 \mu \mathrm{g}$ of twice washed and resedimented mitochondria were either dissolved in $0.5 \mathrm{ml}$ Soluene (Packard Instruments, Frankfurt) and counted in $2 \mathrm{ml}$ scintillation fluid, or immunoprecipitated with a mixture of sera (directed against cytochrome $c$, cytochrome $c_{1}$, subunits $\alpha$ and $\beta$ of $F_{1}$ ATPase, cytochrome $c$ peroxidase, the cytoplasmically made subunits IV-VIII of cytochrome oxidase and citrate synthase), washed and counted.

For assaying in vitro import of precursor protein into mitochondria, $5 \mu \mathrm{g}$ of total yeast poly $\mathrm{A}^{-} \mathrm{RNA}$ [41] was translated in $100 \mu \mathrm{l}$ of nuclease-treated rabbit reticulocyte lysate [42], supplemented with $100 \mu \mathrm{Ci}\left[{ }^{35}\right.$ S $]$ methionine. After $60 \mathrm{~min}$ synthesis at $37^{\circ} \mathrm{C}, 25 \mu \mathrm{l}$ of the post-ribosomal supernatant $(100000 \times g, 10 \mathrm{~min}$, Beckman Airfuge) were freed from unincorporated label by a passage over a Sephadex G50 column. $3 \times 10^{7} \mathrm{cpm}$ equivalent of labeled precursors were incubated with $50 \mu \mathrm{g}$ of freshly prepared mitochondria for $60 \mathrm{~min}$ at $25^{\circ} \mathrm{C}$ in the presence of $0.6 \mathrm{M}$ sorbitol with or without $20 \mu \mathrm{M}$ cAMP. After re-isolation mitochondria were treated with trypsin $\left(120 \mu \mathrm{g} / \mathrm{ml}, 0^{\circ} \mathrm{C}, 30 \mathrm{~min}\right) .1 .2 \mathrm{mg} / \mathrm{ml}$ of soybean trypsin inhibitor and $2 \mathrm{~mm}$ tosyl lysyl chloromethyl ketone terminated the digestion. Then the re-isolated and washed (three times) mitochondria were either spotted on filters, washed and directly counted or immunoprecipitated with a mixture of antisera as above, washed and counted.

\section{Exchange of cAMP by isolated mitochondria}

Forward exchange rates by isolated mitochondria of labeled cAMP and other nucleotides was determined by the silicon oil layer centrifugal filtration technique essentially as described by Klingenberg and Pfaff [43]. Mitochondria were prepared from 
spheroplasts [30] of strain D273-10 B grown on 2\% lactate or $\mathrm{DH} 1$ op $_{1}$ grown on $1.8 \%$ galactose. Mitochondria were washed twice with $0.6 \mathrm{~m}$ mannitol, $25 \mathrm{~mm}$ Tris-maleate, $\mathrm{pH} 6.5,1 \mathrm{~mm}$ EDTA, $0.1 \%$ bovine serum albumin and resuspended at $2.0 \mathrm{mg}$ protein per $\mathrm{ml}$ in storage buffer containing ().35 m mannitol, $25 \mathrm{~mm}$ Tris-maleate, $\mathrm{pH} 6.5$, $0.2 \mathrm{~mm}$ EGTA, $1 \mathrm{~mm} \mathrm{MgCl}_{2}, 0.1 \%$ bovine serum albumin. In a siliconized $3.5 \mathrm{ml}$ pyrex tube (DuPontSorvall) the following components were successively layered on top of each other: $0.35 \mathrm{ml} \mathrm{CsCl}(\mathrm{Q}=$ $1.10 \mathrm{~g} / \mathrm{ml}) .0 .6 \mathrm{ml}$ silicon oil $\mathrm{Q}=1.078 \mathrm{~g} / \mathrm{ml}($ AR 200 Wacker Chemie, Burghausen), 0.1-2.1 ml incubation layer. containing in storage buffer additionally $18 \mathrm{mg} / \mathrm{ml}$ dextrane $\mathrm{T} 40$ and $0.1 \mu \mathrm{Ci} / \mathrm{ml}\left[{ }^{1+} \mathrm{C}\right]$-labeled compound (either ATP, ADP, cAMP, sucrose or polyethylene glycol $60000,500 \mu \mathrm{M}$ final concentration, each). $0.2 \mathrm{ml}$ separation layer, containing in storage buffer additionally $12 \mathrm{mg} / \mathrm{ml}$ dextrane $\mathrm{T} 40$, $0.2 \mathrm{ml}$ mitochondrial suspension $(0.4 \mathrm{mg}$ protein) in storage buffer and $2.0-0 \mathrm{ml}$ of a balancing layer containing $0.1 \mathrm{~m}$ mannitol, $25 \mathrm{~mm}$ Tris-maleate, $0.2 \mathrm{~mm}$ EGTA, pH 6.5. Atractylate $(100 \mu \mathrm{M})$, bongkrecic acid $(20 \mu \mathrm{M})$ or carbonyl cyanide m-chlorophenyl hydrazone $(15 \mu \mathrm{M})$ were used in the control experiments. The tubes were then placed in nitrocellulose tubes filled with $1 \mathrm{~m}$ sucrose solution for stabilization and centrifuged in a SW 27 rotor until a velocity of $16000 \mathrm{rpm}$ was reached. The $\mathrm{CsCl}$ layer was removed and counted. Different incubation periods were achieved by the variation of the volume of the incubation layer from $0.1-2.1 \mathrm{ml}$. Sedimentation velocities were calculated according to [44] and corrections for adhering medium were applied by subtracting the cpm-values measured after incubation with polyethylene glycol [45], which does not penetrate mitochondrial membranes. Uptake of sucrose measured the freely permeable intermembrane space.

Back exchange of adenine nucleotides was measured with mitochondria pre-loaded with the respective $\left[{ }^{3} \mathrm{H}\right]$-labeled carrier-free compound at $4{ }^{\circ} \mathrm{C}$ as described [46]. After sedimentation and two brief washings in an Eppendorf microcentrifuge $(2 \mathrm{~min}$. $\left.4{ }^{\circ} \mathrm{C}\right)$, mitochondria $(0.4 \mathrm{mg}$ protein) were incubated in $1 \mathrm{ml}$ storage buffer as above, containing $15 \mathrm{~mm}$ of unlabeled nucleotide, for $6 \mathrm{~min}$ at room temperature. Then mitochondria were sedimented and supernatant and mitochondrial pellet collected separately for counting.
Inside-out mitochondrial particles were obtained by sonication of mitochondria (about $10 \mathrm{mg} / \mathrm{ml}$ protein) in $250 \mathrm{~mm}$ sucrose, $10 \mathrm{~mm}$ Tris acetate, $1 \mathrm{~mm}$ EGTA, $1 \mathrm{~mm} \mathrm{MgCl}$, pH 7.2, 10 pulses of $5 \mathrm{sec}$ each cooled by an ice-salt mixture. After removal of a low speed pellet $(10 \mathrm{~min}, 12000 \times \mathrm{g})$ sonic particles were sedimented by centrifugation for $90 \mathrm{~min}$ at $145000 \times g$ and resuspended in storage buffer at $2 \mathrm{mg}$ protein $/ \mathrm{ml}$.

\section{Results}

\section{cAMP-binding to mitochondrial proteins}

Mitochondria, prepared from yeast cells either after enzymatic digestion of the cell walls and osmotic shock of the spheroplasts [30], or after carefully shaking with glass beads by hand to a fraction of $60-70 \%$ disrupted cells [31], were further purified by centrifugation on isokinetic urographin gradients [28]. Whole mitochondria with their outer and inner membranes intact were isolated, washed and subjected to mitochondrial subfractionation using porin, cytochrome $b_{2}$, cytochrome $c_{1}$ and aconitase as specific markers for outer membranes, intermembrane space, inner membranes and soluble matrix, respectively [28].

cAMP-binding in the subfractions was measured as shown in Tables I and II. Significant cAMP-binding is associated with whole mitochondria, the specific binding exceeding that of the total cellular homogenate. The bulk of the binding activity sediments with mitochondrial membrane particles after hypotonic disruption of mitochondria, and only a minor, but significant portion is consistently found in the soluble supernatant in the absence of detergents. Zwittergent 14 (or Mega 10 or CHAPS, not shown) solubilize more than $95 \%$ of the cAMP-binding activity from the particulate fraction (Table I).

After fractionation of whole mitochondria into the four submitochondrial compartments in the complete absence of detergents, most of the cAMP-binding resides in the inner membrane (Table II). But significant ligand binding of high specific activity is coincidently observed, with the two binding assays applied, in the soluble intermembrane space fraction. The fact that the sum of binding activities recovered in inner membranes and intermembrane space is much less than originally present in whole mitochondria is caused primarily by the low stability of the binding site even under optimal conditions. 
Table 1. cAMP-binding to yeast cellular subfractions Yeast cells were broken either by osmotic lysis of spheroplasts "or by careful shaking with glass beads by hand "and homogenate, $100000 \times g$ cytoplasmic supernatant and purified mitochondria prepared as detailed in Materials and Methods. Whole mitochondria were homogenized by 20 strokes in a teflon in glass homogenizer in a buffer containing $20 \mathrm{~mm} \mathrm{NaH} \mathrm{PO}_{4}, 0.5 \mathrm{~mm}$ EDTA, $0.5 \mathrm{~mm}$ phenylmethylsulfonyl fluoride and separated at $100000 \times g$ into soluble supernatant and membranes, respectively, for $10 \mathrm{~min}$ at $4{ }^{\circ} \mathrm{C}$ in a Beckman Airfuge. Mitochondrial membranes were solubilized by $5 \mathrm{~mm}$ Zwittergent 14 in the same buffer as above containing in addition $10 \mathrm{~mm} \mathrm{MgCl}$ and $15 \%$ glycerol and centrifuged as above. cAMP-binding was measured by the filter binding assay or by equilibrium dialysis $[28,32]$. Each value represents the average from 3 (filter assay) or 5 (equilibrium dialysis) determinations. Experimental deviations are in the range of $<10 \%$.

cAMP-binding [pmol/mg protein]

Filter assay Equilibrium dialysis

\begin{tabular}{lcc}
\hline Cell homogenate & $1.1^{\mathrm{a}}$ & $0.93^{\mathrm{a}}$ \\
$\begin{array}{l}\text { Cytoplasmic supernatant } \\
(100000 \times g)\end{array}$ & $1.5^{\mathrm{a}}$ & $1.26^{\mathrm{a}}$ \\
Whole purified mitochondria & $1.6^{\mathrm{a}}$ & $1.32^{\mathrm{a}}$ \\
& $2.0^{\mathrm{b}}$ & $1.25^{\mathrm{b}}$ \\
Mitochondrial soluble & - & $1.05^{\mathrm{a}}$ \\
protein & - & $1.35^{\mathrm{b}}$ \\
Mitochondrial & - & $1.40^{\mathrm{a}}$ \\
membranes & - & $1.30^{\mathrm{h}}$ \\
Mitochondrial membranes solubilized & \\
with Zwittergent 14 & - & $1.22^{\mathrm{a}}$ \\
Non-solubilizable residue & - & $00^{\mathrm{a}}$
\end{tabular}

Table II. cAMP-binding in yeast submitochondrial fractions. Mitochondria were prepared from spheroplasts and purified by isokinetic Urographin gradient centrifugation. (The experiment is different from that shown in Table I.) Mitochondria (54 mg) were subfractionated [28] into outer membranes $(1.2 \mathrm{mg})$, intermembrane space $(3.0 \mathrm{mg})$, inner membranes $(13.4 \mathrm{mg})$, and matrix $(14.6 \mathrm{mg})$. Protein yield $59 \%$; yield in cAMP-binding activity $33 \%$. cAMPbinding was measured by equilibrium dialysis using $100 \mu \mathrm{g}$ mitochondrial protein for each assay. Each value represents the mean from 3 binding assays.

\begin{tabular}{lrl}
\hline & \multicolumn{2}{c}{ cAMP-binding } \\
& $\begin{array}{l}\text { Total } \\
\text { activity } \\
\text { [pmol] }\end{array}$ & $\begin{array}{l}\text { Specific } \\
\text { activity } \\
\text { [pmol/mg } \\
\text { protein] }\end{array}$ \\
& & 1.62 \\
& 87.5 & 0.06 \\
Whole purified mitochondria & 0.1 & 1.04 \\
Outer membranes & 3.1 & 1.70 \\
Intermembrane space & 22.8 & 0.21 \\
Inner membranes & 3.0 & \\
Soluble matrix & & \\
\hline
\end{tabular}

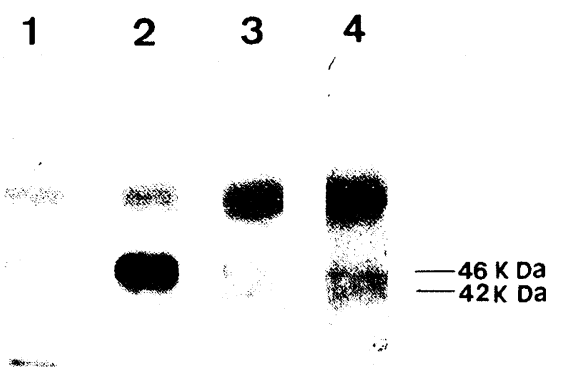

Fig. 1. Photoaffinity labelling of mitochondrial proteins with $8-\mathrm{N}_{3}\left[{ }^{32} \mathrm{P}\right] \mathrm{cAMP}$. Mitochondria were subfractionated into membranes (lanes 1 and 2) and soluble fraction (lanes 3 and 4 ) by homogenization in hypotonic medium and centrifugation at $105000 \times g(20 \mathrm{~min}) .50 \mu \mathrm{g}$ of the membranes and $20 \mu \mathrm{g}$ of the soluble fraction were incubated with $0.5 \mu \mathrm{Ci} 8-\mathrm{N}_{3}\left[{ }^{32} \mathrm{P}\right] \mathrm{cAMP}$ in the presence (lanes 1 and 3 ) or absence (lanes 2 and 4 ) of 10 um unlabeled cAMP. fractionated by polyacrylamide gel electrophoresis and autoradiographed. The markers used were bovine serum albumin $(67 \mathrm{kDa})$, ovalbumin $(45 \mathrm{kDa})$. carbonic anhydrase $(29 \mathrm{kDa})$, chymotrypsinogen $(24.5 \mathrm{kDa})$. myoglobin (17.8 kDa) and cytochrome $c(12.5 \mathrm{kDa})$.

Fig. 1 shows that by photoaffinity labelling with $\mathrm{N}^{\mathrm{s}}$-azido [ $\left.{ }^{32} \mathrm{P}\right]$ cAMP two different binding proteins can be detected in yeast mitochondria, both of which are distinct from the one present in the cytoplasm. The larger cAMP-binding protein $\left(M_{\mathrm{r}} 45-46 \mathrm{kDa}\right)$ is found associated with the inner mitochondrial membrane (lane 2) and is apparently identical with that previously observed in mitochondria [28]. The smaller $\left(M_{\mathrm{r}} 42000\right)$ is localized in the soluble intermembrane space (lane 4). Since the other bands observed after photoaffinity-labelling cannot be competed for by an excess of unlabeled cAMP. these data provide solid evidence that only two different cAMP-binding proteins occur in yeast mitochondria.

\section{cAMP-dependent protein kinase activity in mitochondria}

To test whether any of these two cAMP-binding activities is associated with a protein kinase and might represent its regulatory subunit, we assayed both the intermembrane space and the inner membranes for cAMP-dependent protein kinase activity. In the separate fractions (as well as in the matrix and 
in outer membranes, not shown) no such activity was found in the absence of exogenous substrate. However, when the two neighbouring fractions were incubated together, cAMP-dependent phosphorylation was observed - beside cAMP-independent phosphate incorporation (Table III). Providing exogenous substrates. an effect by cAMP was evident also in individual subfractions, particularly with the intermembrane space. With inner membranes a stimulation by cAMP is not evident. This different capability to phosphorylate exogenous substrates by inner membranes and intermembrane space could indicate that i) the two cAMP receptors present commonly regulate one single kinase, localized in the intermembrane space, ii) that two different kinases are present, one of which is membrane-associated and, being specific, does not accept exogenous substrates, iii) that a very active protein phosphatase masks protein phosphorylation in the inner membrane, or, iv) that the cAMP-receptor of the inner membrane has a function different from a regulatory subunit of a protein kinase. Table III reveals also that acidic substrates are preferentially phosphorylated over histone fractions and bovine serum albumin, phosvitin being an even better substrate than casein.

These properties and substrate preferences clearly distinguish the mitochondrial cAMP-dependent protein kinase from its cytoplasmic counterpart which preferentially phosphorylates histone fractions [4].

Fig. 2 shows that the time course of phosphate incorporation is linear with time under the conditions applied for at least $40 \mathrm{~min}$ with all fractions used, also in the presence of exogenous substrates (casein is given as an example).
Effects of (AMP on mitochondrial macromolecular syntheses and protein import

We were now interested in the role cAMP and the cAMP-dependent mitochondrial protein kinase might play in cell life. For example. it had been observed that mitochondrial RNA polymerase is a repressible activity [47] and that exogenous cAMP stimulates mitochondrial gene expression [19] and respiration [20]. As a first approach to answering the question whether mitochondria themselves can use cAMP as a signal and transmit it to the respiratory machinery in one way or another, we screened the major processes involved in the biogenesis of mitochondria, namely transcription, translation and import of cytoplasmically synthesized precursors of mitochondrial proteins for an effect of cAMP.

The results of these experiments are compiled in Table IV. It can be seen that cAMP has little influence on mitochondrial gene expression, or, rather. that it acts slightly inhibitory. This is particularly evident from an experiment using an enriched fraction of mitochondrial RNA polymerase (prepared as in [29]). These results suggest that cAMP does not stimulate the bulk of either mitochondrial transcription or translation.

Next we examined whether the stimulation of oxygen consumption observed in yeast spheroplasts after the administration of cAMP [20] could be caused by a cAMP-dependent activation of an import channel or processing pathway for mitochondrial proteins made in the cytoplasm. Such a control could satisfactorily explain cAMP-dependent effects in mitochondria. On the other hand phosphorylation of precur-

Table III. Protein kinase activity and stimulation by cAMP in mitochondria and mitochondrial subfractions with endogenous and exogenous substrates in vitro. Mitochondria were subfractionated as described under Table II and incorporation of ${ }^{3-P}$ from $\gamma\left[{ }^{32} \mathrm{P}\right] \mathrm{ATP}$ into acid insoluble material assayed as detailed in Materials and Methods. Protein kinase activity is given as pmol ${ }^{32} \mathrm{P}$ incorporated per $\mathrm{mg}$ mitochondrial protein per $\mathrm{h}$. cAMP-dependent protein kinase activity is approximated by the difference between the kinase activities measured in the presence and in the absence of cAMP.

\begin{tabular}{|c|c|c|c|c|c|c|c|c|c|c|c|c|}
\hline \multirow[b]{2}{*}{$\begin{array}{l}\text { Exogenous } \\
\text { substrate }\end{array}$} & \multicolumn{3}{|c|}{$\begin{array}{l}\text { Whole } \\
\text { mitochondria }\end{array}$} & \multicolumn{3}{|c|}{$\begin{array}{l}\text { Inner } \\
\text { membranes }\end{array}$} & \multicolumn{3}{|c|}{$\begin{array}{l}\text { Intermem. } \\
\text { space }\end{array}$} & \multicolumn{3}{|c|}{$\begin{array}{l}\text { Inner membranes } \\
+ \text { interm. space }\end{array}$} \\
\hline & cAMP & $\begin{array}{l}+ \\
\text { cAMP }\end{array}$ & $\begin{array}{l}\text { cAMP } \\
\text { dep. }\end{array}$ & cAMP & $\begin{array}{l}+ \\
\text { cAMP }\end{array}$ & $\begin{array}{l}\text { cAMP } \\
\text { dep. }\end{array}$ & cAMP & $\begin{array}{l}+ \\
\text { cAMP }\end{array}$ & $\begin{array}{l}\text { cAMP } \\
\text { dep. }\end{array}$ & $\overline{\text { cAMP }}$ & $\begin{array}{l}+ \\
\text { cAMP }\end{array}$ & $\begin{array}{l}\text { cAMP } \\
\text { dep. }\end{array}$ \\
\hline None & 87 & 91 & 4 & 89 & 94 & 5 & 3.4 & 3.5 & 0.1 & 74 & 97 & 23 \\
\hline Phosvitin & 129 & 148 & 19 & 138 & 142 & 4 & 8.5 & 71 & 63 & 120 & 262 & 142 \\
\hline Casein & 108 & 126 & 18 & 119 & 106 & 0 & 6.0 & 56 & 50 & 103 & 228 & 125 \\
\hline $\begin{array}{l}\text { Bovine s. } \\
\text { albumin }\end{array}$ & 91 & 96 & 5 & 90 & 91 & 1 & 0.3 & 13.6 & 13 & 0.4 & 31.5 & 31 \\
\hline Histone $\mathrm{V}$ & 86 & 90 & 4 & 94 & 95 & 1 & 3.0 & 16.3 & 13 & 5.5 & 48.0 & 42 \\
\hline Histone VIII & 86 & 89 & 3 & 95 & 91 & 0 & 5.5 & 5.5 & 0 & 0.5 & 31.5 & 31 \\
\hline
\end{tabular}




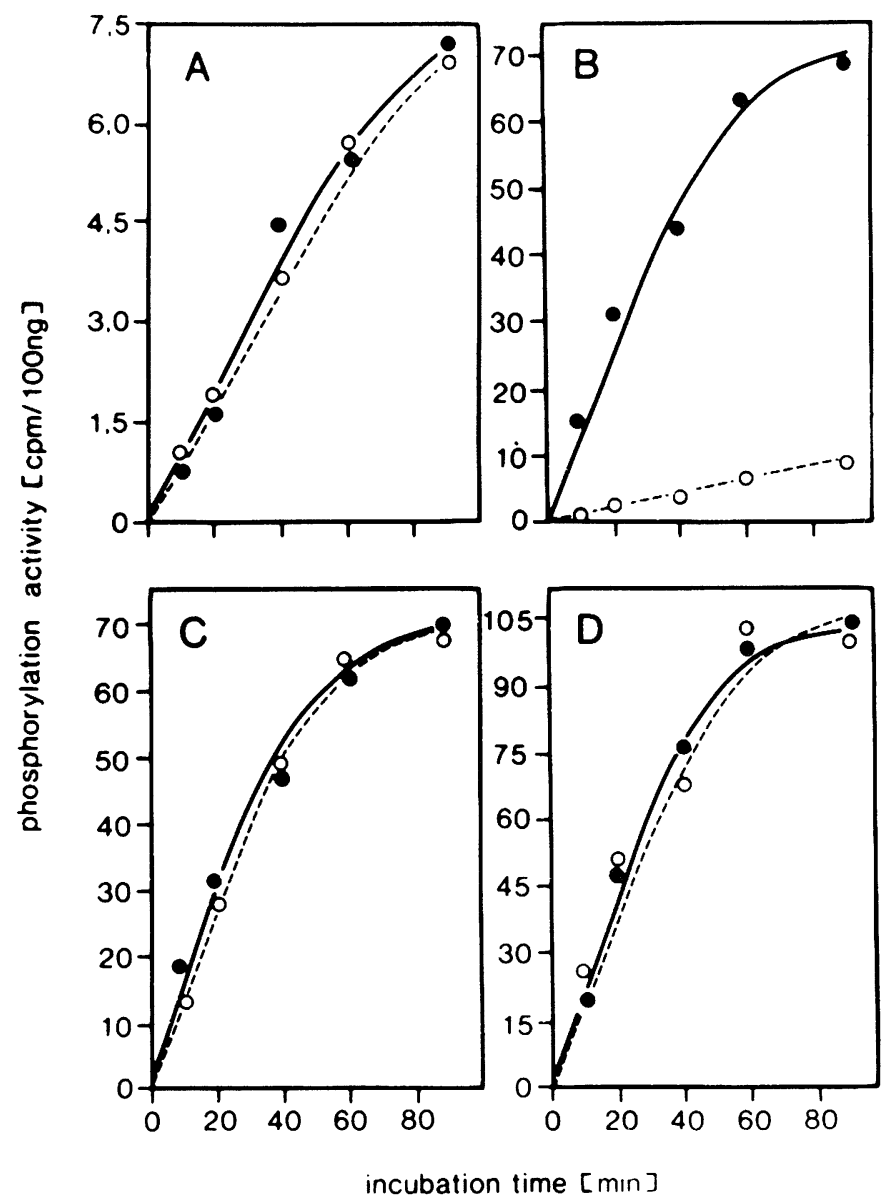

Fig. 2. Kinetics of protein kinase activity. Mitochondrial subfractions were incubated with $\gamma\left[{ }^{3} \mathrm{P}\right] \mathrm{ATP}$ in the absence $(\mathrm{O}---\mathrm{O})$ and presence (-) of cAMP and with endogenous (A. C) or exogenous (B. D) substrate (see Materials and Methods). A. intermembrane space proteins: B. intermembrane space plus casein: $C$. inner membranes: D, inner membranes plus casein.

Table IV. Influence by cAMP on mitochondrial macromolecular syntheses and on the import of precursor proteins into the organelle in vivo and in ritro. All data given represent counts per minute. ". Mitochondrial transcription was measured by hybridization of labeled mitochondrial RNA to filter-bound mitochondrial DNA. ". Protein import reflects carbamyl cyanide m-chlorophenyl hydrazone-sensitive. trypsin resistant incorporation of labeled protein into mitochondria. "Immunoprecipitation was performed with a mixture of sera directed against subunits $\alpha$ and $\beta$ of $F_{1}$-ATPase. subunits IV - VIII of cytochrome $c$ oxidase, cytochromes $c$ and $c_{1}$. cytochrome $c$ peroxidase and citrate synthetase. ". Values give $\mathrm{cpm}{ }^{3} \mathrm{H}$-pulse label per $1000 \mathrm{cpm}{ }^{1+} \mathrm{C}$-prelabel. ". Run-off transcription in intact mitochondria with endogenous template. '. Transcription in lysed mitochondria with poly $[\mathrm{dA} \cdot \mathrm{dT}]$ as template. ‥ Transcription with enriched RNA polymerase and poly[dA $\cdot \mathrm{dT}]$ as template $[29,38]$. ". Import of precursors synthesized by a reticulocyte lysate programmed with yeast poly $\mathrm{A}^{+}$RNA; total in ritro synthesized yeast polypeptides equal $3.0 \times 10^{7} \mathrm{cpm}$ in each experiment.

\begin{tabular}{|c|c|c|c|c|c|c|c|c|}
\hline & \multicolumn{2}{|c|}{$\begin{array}{l}\text { Mitochondrial } \\
\text { transcription" }\end{array}$} & \multicolumn{2}{|c|}{$\begin{array}{l}\text { Mitochondrial } \\
\text { translation }\end{array}$} & \multicolumn{2}{|c|}{$\begin{array}{l}\text { Mitochondrial } \\
\text { total import }\end{array}$} & \multicolumn{2}{|c|}{$\begin{array}{l}\text { Immune } \\
\text { precipitate }^{1 . c}\end{array}$} \\
\hline & -cAMP & +cAMP & -cAMP & $+\mathrm{cAMP}$ & -cAMP & $+c A M P$ & - cAMP & +cAMP \\
\hline $\begin{array}{l}\text { Derepressed } \\
\text { cells }\end{array}$ & $6.50^{4}$ & $580^{4}$ & $3500^{\mathrm{d}}$ & $40000^{d}$ & 95200 & 87800 & 1800 & 2700 \\
\hline $\begin{array}{l}\text { Repressed } \\
\text { cells }\end{array}$ & $360^{\mathrm{d}}$ & $350^{\mathrm{d}}$ & $2300^{\mathrm{d}}$ & $2500^{\mathrm{d}}$ & 32200 & 34500 & 800 & 1500 \\
\hline $\begin{array}{l}\text { Derepressed } \\
\text { mitochondria }\end{array}$ & $\begin{array}{c}7400^{\prime \prime} \\
19100^{f} \\
340\left(0^{\prime}\right.\end{array}$ & $\begin{array}{r}7000^{\mathrm{a}} \\
190\left(00^{\mathrm{i}}\right. \\
210\left(0^{\mathrm{g}}\right.\end{array}$ & 7000 & 6100 & $141000^{11}$ & 8400 & $1100^{\mathrm{h}}$ & $700^{\mathrm{h}}$ \\
\hline $\begin{array}{l}\text { Repressed } \\
\text { mitochondria }\end{array}$ & $\begin{array}{r}44000^{* 1} \\
10300^{f}\end{array}$ & $\begin{array}{r}4900^{\mathrm{a}} \\
10800^{\mathrm{r}}\end{array}$ & 4600 & 2200 & $56000^{h}$ & $500\left(00^{\mathrm{h}}\right.$ & $400^{h}$ & $4000^{\mathrm{h}}$ \\
\hline
\end{tabular}


sors to be transported has been observed both with mitochondria ( $\alpha$-subunit of $F_{1}$-ATPase, [48]) and chloroplasts (ribulose bisphosphate carboxylase. small subunit. [9]).

Table IV shows the results of two experiments. One was performed in vivo, the other with isolated mitochondria. Energy-dependence of this process [39] and resistance to protease of imported proteins [40] were taken as criteria for mitochondrial precursor import. Both total import into mitochondria and the import of a few individual proteins after quantitative immunoprecipitation by a mixture of sera was measured. In the in vivo experiment the import had been impaired by carbamyl cyanide m-chlorophenyl hydrazone during the radioactive pulse thus allowing the accumulation of mitochondrial precursors in the cytoplasm [39]. After a chase, subsequent restoration of energy coupling by addition of SH-reagents initiated the import [39]. The influence of cAMP on this import was tested.

For measuring import into isolated mitochondria a reticulocyte lysate was programmed with yeast poly $\mathrm{A}^{-}$RNA and the proteins made were labeled with $\left[{ }^{35}\right]$ methionine. Then purified mitochondria were added and the import of labeled precursors was as-

Table V. Effects of various nucleotides on the respiration of repressed (YPD, 6\% glucose) and derepressed (YPL. $2 \%$ lactate) cells of strain D273-10B after 4 h of incubation with $2 \mathrm{~mm}$ effector at $\mathrm{pH} 4.4$. Respiratory rates are expressed as $\mathrm{nmol} 0, \min \times 10^{\circ}$ cells. $\mathrm{DB}=$ dibutyryl. $\mathrm{MB}=$ monobutyryl.

\begin{tabular}{|c|c|c|}
\hline $\begin{array}{l}\text { Growth } \\
\text { conditions }\end{array}$ & Additions & $\begin{array}{l}\text { Respiratory } \\
\text { rates }\end{array}$ \\
\hline \multirow{14}{*}{$\begin{array}{l}\text { YPD } \\
\text { (repressed) }\end{array}$} & none & 62 \\
\hline & $\mathrm{N}^{6}-\mathrm{DBCAMP}$ & 60 \\
\hline & $\mathrm{O}^{2}-\mathrm{MBCAMP}$ & 72 \\
\hline & $N^{0}-M B c A M P$ & 120 \\
\hline & $3^{\prime}: 5^{\prime}-\mathrm{cAMP}$ & 125 \\
\hline & $3^{\prime}: 5^{\prime}-c G M P$ & 90 \\
\hline & $\mathrm{N}^{\prime \prime}-\mathrm{MBcAMP}+5^{\prime}-\mathrm{AMP}$ & 90 \\
\hline & $3^{\prime}: 5^{\prime}-\mathrm{cAMP}+5^{\prime}-\mathrm{AMP}$ & 112 \\
\hline & ATP & 84 \\
\hline & ADP & 94 \\
\hline & GTP & 71 \\
\hline & $5^{\prime}-\mathrm{AMP}$ & 98 \\
\hline & $3^{\prime}-\mathrm{AMP}$ & 78 \\
\hline & $2^{\prime}-\mathrm{AMP}$ & 79 \\
\hline \multirow{3}{*}{$\begin{array}{l}\text { YPL } \\
\text { (derepressed) }\end{array}$} & none & 445 \\
\hline & $N^{\prime \prime}-M B c A M P$ & 415 \\
\hline & $3^{\prime}: 5^{\prime}-c A M P$ & 395 \\
\hline
\end{tabular}

sayed in the presence or absence of cAMP. In both cases no pronounced influence of cAMP on total precursor import could be detected (Table IV).

Apart from total incorporation, a few proteins were assayed individually by quantitative immune precipitation (see legend to Table IV). Again no obvious influence by cAMP could be detected. Thus a control by cAMP of a general import pathway is very unlikely. But it cannot principally be excluded that for the import of yet one or a limited number of proteins (e.g. RNA polymerase) cAMP could play a role.

Table $\mathrm{V}$ reveals that in spheroplasts from glucose grown yeast cells cAMP has, in fact, a small (less than twofold) stimulatory effect on mitochondrial respiration, whereas the effector consistently acts slightly inhibitory in derepressed cells. But as non-cyclic nucleotides have similar effects - confirming earlier results of others [20] - it is concluded that the effect of cAMP on respiration is non-specific.

\section{Does cAMP cross both mitochondrial membranes or only the outer membrane?}

The results shown in Tables IV and V suggest that cAMP does not exert any effect inside the inner mitochondrial compartment. On the other hand it has been reported [50] that cAMP is taken up by isolated mitochondria. We attempted to verify these results and to test whether cAMP traverses the inner mitochondrial membrane.

Fig. $3 \mathrm{~A}$ shows that, in fact. CAMP co-sediments with intact mitochondria in the silicon oil layer centrifugation in a similar fashion as ADP and ATP. The amount taken up considerably exceeds that measured for polyethylene glycol and sucrose known not to penetrate the outer or the inner membranes, respectively. But in strict contrast to ADP, cAMP is also taken up by mitochondria in the presence of bongkrecic acid (or carboxyatractylate (not shown), which block adenine nucleotide translocation, or of the uncoupler carbonyl cyanide m-chlorophenyl hydrazone), as well as by mitochondria from strain DH 1 op $_{1}$ (Fig. 3 B) blocked by mutation in the ADP/ ATP translocation [51]. Under the latter conditions, uptake of ATP is reduced to the level of sucrose, which is known not to traverse the inner mitochondrial membrane, whereas that of cAMP is not significantly diminished. Inside-out particles, prepared by sonic oscillation and freed from most of the matrix, 

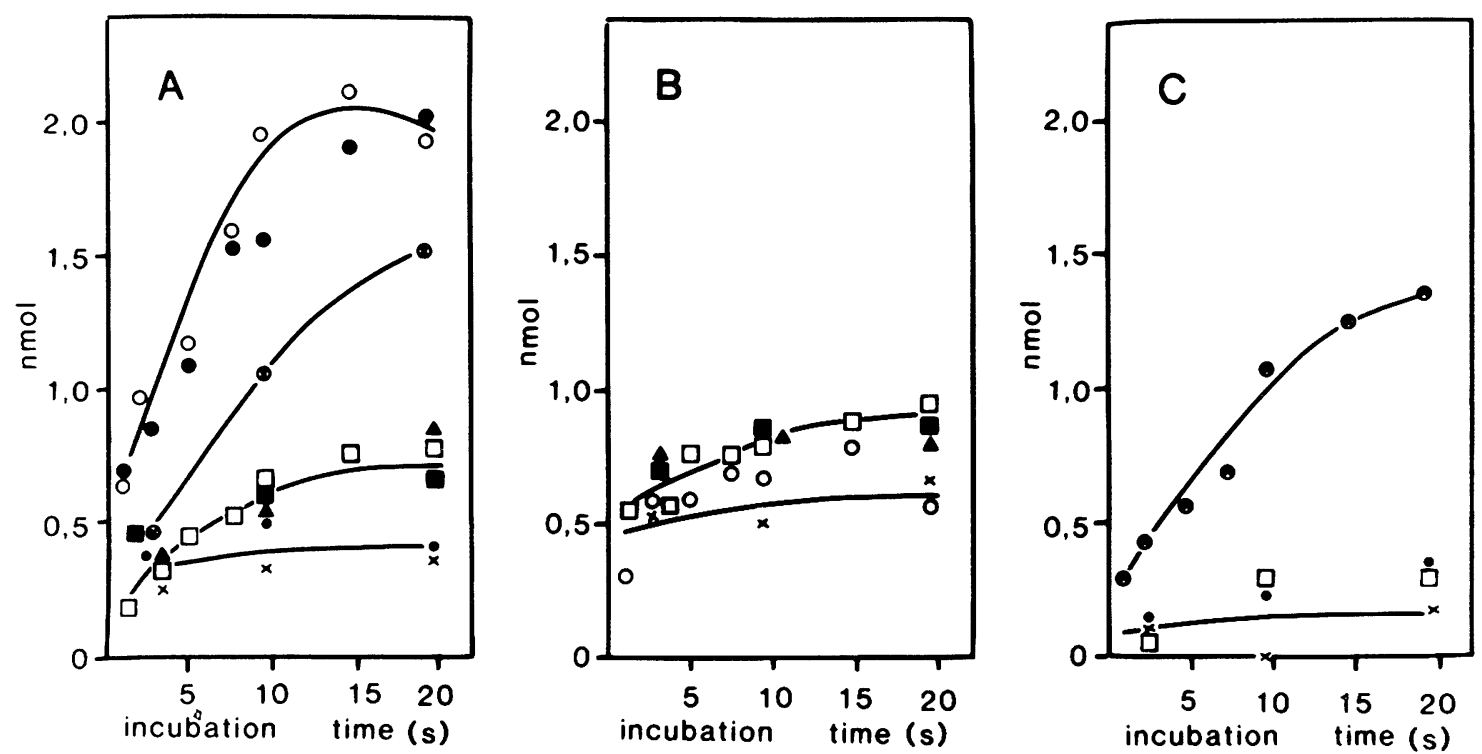

Fig. 3. Forward exchange by isolated mitochondria of cAMP in comparison to ATP and ADP. The uptake of ${ }^{1+} C$-labeled compounds $(500)(\mathrm{M})$ was measured by the silicon oil layer filtration technique [4.3] as detailed in Materials and Methods. All values were corrected for labeled solute adhering to mitochondria during the passage through the oil layer by subtraction of the value obtained after incubation with polyethylene glycol. Mitochondria are impermeable to this polyme [45]. Uptake of labeled sucrose above this background measured the intermembrane space, which is freely permeable to low molecular weight substances. Controls were performed in the presence of $20 \mu \mathrm{m}$ bongkrecic acid (BA) or $15 \mu \mathrm{m}$ carbonyl cyanide m-chlorophenyl hydrazone (CCCP). A. whole mitochondria from wild type yeast: $B$. mitochondria from mutant strain DH $1 \mathrm{op}_{1}$. defective in adenine nucleotide translocation [51]: C. inside-out particles. $\square$. cAMP: $\mathbf{D}$. cAMP + $\mathrm{BA} ; \boldsymbol{\triangle}, \mathrm{cAMP}+\mathrm{CCCP} ;$ О. ADP; $\otimes . \mathrm{ATP} ; \bullet, \mathrm{ADP}+\mathrm{BA}: \bullet . \mathrm{ADP}+\mathrm{CCCP}: \times$. sucrose.

well accumulate ATP but retain only insignificant amounts of cAMP. The fraction of the latter correlates well with the portion of right side-out particles present in the preparation (Fig. 3C).

Table VI shows an experiment in which isolated wild type mitochondria were pre-loaded with either labeled cAMP, ATP or sucrose and then incubated in the presence or absence of excess unlabeled solute in order to measure the velocity of the back exchange. In the case of mitochondria pre-loaded with CAMP and with ATP in the presence of atractylate significant label is retained with mitochondria after centrifugation and only a minor fraction found in the supernatant. The label is, however, rapidly released into the supernatant (within $6 \mathrm{~min}$ ) in all other cases.

Taken together these experiments show that cAMP-uptake by mitochondria is independent on the adenine nucleotide translocator and on a membrane potential (Fig. 3A + B. Table VI). Since in insideout particles (Fig. 3C) uptake of cAMP is diminished to a level close to that of sucrose (and polyethylene glycol) it is concluded that cAMP does not traverse the inner mitochondrial membrane to a significant

Table VI. Release of labeled solutes into the supernatant from preloaded mitochondria in the presence of excess unlabeled solute ("back exchange"). All data are given as cpm. Atr = atractylate. Atractylate was present also during the washing of preloaded mitochondria.

\begin{tabular}{lcccc}
\hline & {$\left[{ }^{3} \mathrm{H}\right]$ ATP } & ["H]ATP + Atr & ['H]cAMP & ['H]sucrose \\
\hline Radioactivity in mitochondria & 17700 & 22800 & 5800 & 110 \\
Radioactivity retained & 2130 & 21700 & 5380 & 10 \\
Radioactivity released & 16900 & 2900 & 590 & 115 \\
\% of compound exchanged & 88.9 & 11.7 & 9.8 & 92 \\
\hline
\end{tabular}


extent. Uptake of cAMP by whole mitochondria is, however, significantly higher than that of sucrose suggesting that it binds to some receptor(s) outside the permeability barrier provided by the inner mitochondrial membrane. This is consistent with earlier topological studies of cAMP-binding in mitochondria [28].

\section{Discussion}

The recent demonstration of cAMP-binding to (a) mitochondrial receptor protein(s) [28] leaves the question unanswered whether this protein participates in the glucose repression/derepression mechanism of mitochondria and whether it controls mitochondrial gene expression in a manner analogous to the positive transcriptional regulation found in E. coli and other bacteria. Alternatively, it could constitute the regulatory subunit of a cAMP-dependent protein kinase, so that mitochondria follow eukaryotic principles of regulation. Here we demonstrate for the first time that yeast mitochondria harbour at least one cAMP-dependent protein kinase, which hints at the latter possibility. Moreover, we provide some evidence that two different cAMPbinding proteins are present in intact mitochondria. They are clearly distinct from one another and from the cytoplasmic regulatory subunit in terms of molecular mass and substrate preference. One of the two cAMP-binding proteins $\left(M_{\mathrm{r}} 45-46000\right)$ is bound to the outer surface of the inner mitochondrial membrane and has been described earlier ([28], Müller, Bandlow, Yeast 3, in the press). The other $\left(M_{\mathrm{r}}\right.$ $42000)$, too, is localized outside the permeability barrier provided by the inner mitochondrial membrane and is found in the soluble intermembrane space. For the cytoplasmic regulatory subunit a molecular weight of 50000 has been reported [4]. The mitochondrial kinase catalyzes phosphate incorporation into acidic proteins whereas the cytoplasmic counterpart preferentially phosphorylates histones.
But, nevertheless, it cannot be decided at present, whether these three cAMP-binding proteins represent differently processed forms of the same precursor protein and are encoded by one single structural gene or by different genes. Although unspecific degradation cannot completely be ruled out it appears extremely unlikely because of the presence of protease inhibitors in all buffers. It also is not yet known, whether the two mitochondrial cAMP-binding species regulate the same catalytic subunit, which appears to be localized in the soluble intermembrane space, or whether two different cAMP-dependent protein kinases are present in mitochondria. In vivo and in vitro cAMP-dependent protein kinase activity can hardly be detected with endogenous substrates. It appears very likely that cAMP-dependent phosphorylation is only transient and rapidly removed by a vicinal phosphatase.

cAMP appears to exert all of its effects outside the inner mitochondrial compartment. This finding is consistent with earlier topological studies which have shown ([28] and Müller and Bandlow, Yeast 3, in the press) that the cAMP receptor proteins are localized outside the permeability barrier provided by the inner membrane. Here we have demonstrated that CAMP does not traverse the inner mitochondrial membrane. It was also shown that the ligand does not influence mitochondrial transcription or translation, either in vivo or in vitro which contrasts to earlier reports $[19,20]$. Also at least the bulk portion of the import of cytoplasmically synthesized precursors into mitochondria is, apparently, not influenced by cAMP, either in vivo or in vitro. Thus the physiological role of the mitochondrial cAMP-binding proteins remains to be established.

\section{Acknowledgements}

We thank A. Haid and G. Schatz, The Biocenter Basel, for the gracious donation of antisera, and $G$. Strobel and I. Haberl for their help with the preparation of the figures and the typing of the manuscript. 
[1] G. F. Casperson. N. Walker, A. R. Brasier, and H. R. Bourne. J. Biol. Chem. 258, 7911-7914 (1983).

[2] K. Suoranta and J. Londesborough. J. Biol. Chem. 259, 6964-6971 (1984).

[3] C. Dery. S. Cooper. M. A. Savageau. and S. Scanlon. Biochem. Biophys. Res. Commun. 90, 933-939 (1979).

[4] C. S. Hixson and E. G. Krebs, J. Biol. Chem. 255, 2137-2145 (1980)

[5] P. K. Jaynes, J. P. McDonough, and H. R. Mahler, Biochem. Biophys. Res. Commun. 94, 16-22 (1980).

[6] Y. Takai, H. Yamamura, and Y. Nishizuka, J. Biol. Chem. 249, 530-535 (1974).

[7] P. B. Chock. S. G. Rhee, and E. R. Stadtman. Annu. Rev. Biochem. 49, 813-843 (1980).

[8] J. B. van der Plaat and P. van Solingen. Biochem. Biophys. Res. Commun. 56, 580-587 (1979).

[9] A. L. Boynton and J. F. Whitefield, Adv. Cyclic Nucleotide Res. 15, 193-294 (1983).

[10] D. L. Friedman. R. A. Johnson, and C. E. Zeilig. Adv. Cyclic Nucleotide Res. 7, 69-114 (1976).

[11] I. H. Pastan. G. S. Johnson, and V. B. Anderson. Annu. Rev. Biochem. 44, 491-522 (1975).

[12] J. P. Jost and H. V. Rickenberg. Annu. Rev. Biochem. 40, 741-773 (1971).

[13] G. M. Tomkins, Science 189, 760-763 (1979).

[14] P. Eraso and J. M. Gancedo, Europ. J. Biochem. 141, 195-198 (1984).

[15] K. Matsumoto, I. Uno, T. Ishikawa, and Y. Oshima. J. Bacteriol. 156, 898-900 (1983).

[16] G. Schlanderer and H. Dellweg. Europ. J. Biochem. 49, 305-316 (1974).

[17] R. van Wijk and T. M. Konijn. FEBS Lett. 13, 184-186 (1971).

[18] H. R. Mahler and C. C. Lin. Biochem. Biophys. Res. Commun. 61, 963-970 (1978).

[19] K. Chandrasckaran and J. Jayaraman. FEBS Lett. 87. 52-54 (1978)

[20] M. Fang and R. A. Butow. Biochem. Biophys. Res. Commun. 41, 1579-1583 (1970).

[21] K. Matsumoto, I. Uno, A. Toh-e. T. Ishikawa, and Y. Oshima, J. Bacteriol. 150, 277-285 (1982).

[22] S. Powers, T. Kataoka. O. Fasano, M. Goldfarb, J. Broach, and M. Wigler. Cell 36, 607-612 (1984).

[23] K. Tatchell, L. C. Robinson, and M. Breitenbach. Proc. Natl. Acad. Sci. USA 82, 3785-3789 (1985)

[24] T. Toda, I. Uno, T. Ishikawa, S. Powers, T. Kataoka. D. Broek, S. Cameron. J. Broach, K. Matsumoto. and M. Wigler, Cell 40, 27-36 (1985).

[25] G. L. Temeles, J. B. Gibbs, J. S. D Alonzo, I. S. Sigal, and E. M. Scolnick. Nature (London) 313, $700-703$ (1985).

[26] D. Fraenkel. Proc. Natl. Acad. Sci. USA 82, 4740-4744 (1985).
[27] T. Kataoka. S. Powers. C. McGill. O. Fasano, I. Strathern, J. Broach. and M. Wigler. Cell 37, 437-44.5 (1984).

[28] G. Rödel. G. Müller, and W. Bandlow, J. Bacteriol. 161, 7-12 (1985).

[29] W. Bandlow. U. Schwarz. G. Rödel. G. Strobel, and C. Wachter. Biol. Chem. Hoppe-Seyler 366, 545-5.53 (1985).

[30] H. T. Hutchison and L. H. Hartwell, J. Bacteriol. 94, 1697-1705 (1976).

[31] B. Lang. G. Burger. I. Doxiadis. D. Y. Thomas. W. Bandlow, and F. Kaudewitz. Analyt. Biochem. 77, $110-121$ (1977)

[32] G. M. Walton and L. D. Garren. Biochemistry 9, $4223-4229$ (1970)

[33] W. Bandlow. R. Metzke. A. Klein. K. Kotzias. I. Doxiadis, H. Bechmann. R. J. Schweyen, and F. Kaudewitz, Europ. J. Biochem. 76, 373-382 (1977).

[34] U. Walter and P. Greengard. Meth. Enzymol. 99, $154-162$ (1983).

[35] M. M. Bradford. Analyt. Biochem. 72, 248-254 (1976).

[36] A. Heil and W. Zillig. FEBS Lett. 11, 165-168 (1970).

[37] L. A. Grivell. Biochem. J. 105, 44C-46C (1967).

[38] D. Levens, A. Lustig. and M. Rabinowitz, J. Biol. Chem. 256, 1474-1481 (1981).

[39] G. A. Reid and G. Schatz. J. Biol. Chem. 257, $13056-13060$ (1982).

[40] G. Schatz. S. M. Gasser, and G. Daum. J. Biol. Chem. 257, 13034-13041 (1982).

[41] H. Aviv and P. Leder, Proc. Natl. Acad. Sci. USA 69. $1408-1412$ (1972).

[42] H. R. B. Pelham and R. J. Jackson. Europ. J. Biochem. 67, 247-256 (1976).

[43] M. Klingenberg and E. Pfalf. Meth. Enzymol. 10, $680-684(1967)$

[44] M. Klingenberg. E. Pfalf, and A. Kröger. in: Rapid Mixing and Sampling Techniques in Biochemistry (B. Chance. R. H. Eisenhardt, Q. H. Gibson, and K. K. Lonberg-Holm, eds. ). pp. 333-3.37. Academic Press. New York 1964.

[45] E. Pfaft, M. Klingenberg. E. Ritt, and W. Vogell. Europ. J. Biochem. 5, 222-2.32 (1968).

[46] E. Plaff and M. Klingenberg. Europ. J. Biochem. 6, $66-79(1968)$

[47] D. J. South and H. R. Mahler. Nature 218, 1226-1232 (1968).

[48] R. A. Steinberg. J. Cell Biol. 98, 2174-2178 (1984).

[49] J. Soll and B. B. Buchanan, J. Biol. Chem. 258 , 6686-6689 (1983)

[50] W. Bandlow, Hoppe-Seyler's Z. physiol. Chem. 360, 228-229 (1979).

[51] J. Kolarov. J. Subik, and L. Kováč. Biochim. Biophvs. Acta 267, 465-478 (1972). 